\title{
Pyrolysis characteristics of a North Korean oil shale
}

\author{
Wang Wei ${ }^{1}$, Li Shuyuan ${ }^{1 *}$, Li Linyue ${ }^{1}$, Ma Yue ${ }^{1}$, Yue Changtao ${ }^{1}$ and He Jilai ${ }^{2}$ \\ ${ }^{1}$ State Key Laboratory of Heavy Oil Processing, China University of Petroleum, Beijing 102249, China \\ ${ }^{2}$ Shandong Energy Long-kou Mining Group Co., Ltd., Long-kou, Shandong 265700, China \\ (C) China University of Petroleum (Beijing) and Springer-Verlag Berlin Heidelberg 2014
}

\begin{abstract}
Pyrolysis characteristics of a North Korean oil shale and its pyrolysates were investigated in this paper. The pyrolysis experiments were conducted below $600{ }^{\circ} \mathrm{C}$ at a heating rate of $10,15,20$ and $25{ }^{\circ} \mathrm{C} / \mathrm{min}$, respectively. The kinetics data were calculated using both integral and differential methods with the assumption of first order kinetics. The results show that the averaged oil content of the North Korean oil shale is about $12.1 \mathrm{wt} \%$ and its heat value is $13,400 \mathrm{~kJ} / \mathrm{kg}$. The oil yields at different retorting temperatures show that the higher the retorting temperature the greater the oil and retorting gas yields. The optimal retorting temperature for the North Korean oil shale is about $500{ }^{\circ} \mathrm{C}$. The properties of the North Korean shale oil including density, viscosity, flash point and freezing point are found to be relatively low compared with those of shale oil from FuShun, China. The gasoline fraction, diesel fraction and heavy oil fraction account for $11.5 \mathrm{wt} \%, 41.5 \mathrm{wt} \%$ and $47 \mathrm{wt} \%$, respectively. The major pyrolysis gases are $\mathrm{CH}_{4}$ (the most abundant), $\mathrm{H}_{2}, \mathrm{CO}_{2}, \mathrm{H}_{2} \mathrm{~S}, \mathrm{CO}$, and $\mathrm{C}_{2}-\mathrm{C}_{5}$ hydrocarbons. The heat value of retorting gas is more than $900 \mathrm{~kJ} / \mathrm{mol}$, and the retorting gas has high sulfur content.
\end{abstract}

Key words: Shale oil, pyrolysis, properties, oil shale, retorting, kinetics

\section{Introduction}

Oil shale, as a source of chemical feedstocks, has attracted increasing attention due to the uncertainty of crude oil supplies and the intensification of world energy concerns (Fang et al, 2012; Sert et al, 2012; Qian et al, 2003). Oil shale is a sedimentary rock containing soluble bitumen and insoluble kerogen. Pyrolysis of oil shale can produce shale oil, water, retorting gas and semi-coke ( $\mathrm{Na}$ et al, 2012; Martins et al, 2010; Bhargava et al, 2005). The amount and quality of the oil produced will determine process feasibility both technically and economically. The composition of the oil produced is controlled by the pyrolysis temperature and the reaction time (Williams and Ahmad, 2000; Al-Harahsheh et al, 2011).

Worldwide shale oil resources are abundant and distributed in 33 countries, and the in-place shale oil equivalent of them accounts for about 410 billion tons (Dyni, 2003; Qian and Yin, 2010; Altun et al, 2006b). So far, many investigations of oil shale have been undertaken. The pyrolysis kinetics of Chinese oil shale from different sources are studied with thermo-gravimetric analysis (TGA) (Li and Yue, 2003; Chi et al, 2007; Miao et al; 2011; Bai et al, 2006). It is found that the pyrolysis mechanisms of different oil shale are complex and their first-order kinetics parameters are different from each

*Corresponding author. email: syli@cup.edu.cn

Received October 31, 2013 other. But their plots of $\ln A-E$ (where, $A$ is the frequency factor, $\min ^{-1} ; E$ is the activation energy, $\mathrm{kJ} / \mathrm{mol}$ ) are straight lines according to their different kinetic models. Besides, the pyrolysis of oil shale from Spain, Jordan, Estonia have also been studied (Torrente and Galan, 2001; Al-Ayed et al, 2010; Johannes et al, 2007) and the conclusions agree well with those of Chinese oil shale. The pyrolysis characteristics of oil shale from China and Australia are studied by the topochemical reaction method and techniques including Solid-State ${ }^{13} \mathrm{C}$ NMR, XPS, FT-IR, and XRD (Sun et al, 2014; Wang et al, 2012; Tong et al, 2011; Bhargava et al, 2005). It is found that in air, the topochemical reaction of oil shale generates carbon dioxide and water, and a large amount of heat simultaneously for further self-pyrolysis.

The pyrolysis characteristics of Green River oil shale (USA) are investigated with TGA-MS (Tiwari and Deo, 2012). The results show that the compositions of the pyrolysis products of Green River oil shale are affected by the compositions of the organic matter in oil shale and reaction conditions of overall system or reactor. Many investigations of oil shale from Nigeria (Ehinola et al, 2005), Morocco (El Harfi et al, 2000), and Turkey (Hascakir and Akin, 2010; Altun et al, 2006a) are reported. The dielectric properties of oil shale from Jordan and Green River (USA) have also been studied for developing in-situ electromagnetic (EM) retorting technologies (Al-Harahsheh et al, 2009; Hakala et al, 2011). China, Estonia and Brazil are producing oil from shale commercially. As an unconventional fuel resource, oil shale 
has become a part of diversified energy strategy (Wang and Zhou, 2009; Wang et al, 2010).

Although the pyrolysis characteristics of oil shale have been widely studied by many scholars, to the best of our knowledge there has not been any study on characteristics of North Korean oil shale published. This work is aimed to investigate the pyrolysis characteristics of a North Korean oil shale, including Fischer Assay, heat value, proximate analysis.

\section{Experimental}

\subsection{Sample}

The oil shale samples were from Anzhou Basin in North Korea. Before the experiments, samples were crushed and sieved to eliminate the effects of heat transfer and mass transfer of oil shale particles on pyrolysis characteristics. The oil shale particles less than 200 mesh was used as the experimental sample. Oil shale samples (about $50 \mathrm{~g}$ ) were heated to $520{ }^{\circ} \mathrm{C}$ with the absence of air in Fischer Assay to determine the oil yield from oil shale. The heating value analysis, proximate analysis and ultimate analysis were conducted using a ZDHW-A8 analyzer (Zhengzhou Sanbo Bergwerk Instrument Co. Ltd., China), a HTGF-3000 analyzer (Hebi City HuaTai Instrument Co. Ltd., China) and a LECO CHN-2000 (LECO, USA) and LECO S-144DR analyzer (LECO, USA), respectively. Pyrolysis gases were collected and analyzed off-line by gas chromatography (7890A GC system, Agilent, USA). The analysis of shale oil was carried according to the following Chinese Standards:

GB/T265-88: Petroleum products-Determination of kinematic viscosity and calculation of dynamic viscosity;

GB/T2540-81(88): Petroleum products-Determination of density (Pyknometer method);

GB/T 510-83(91): Petroleum products-Determination of Solidification point;

GB/T261-83(91): Petroleum products-Determination of flash point (Closed cup method);

GB/T508-85(91): Petroleum products-Determination of ash;

GB/T511-2010: Petroleum, Petroleum products and additives-Method for determination of mechanical admixtures;

GB/T260-77(88): Petroleum products-Determination of water;

SH/T0170-92: Petroleum products-Determination of carbon residue (electric stove method);

SH/T0509-92: Petroleum products-Determination of bitumen composition.

\subsection{Apparatus and procedures}

A thermo-gravimetric analyzer (TGA) (NETZSCH STA409PC, NETZSCH, Germany) was used for investigating the pyrolysis kinetics of the North Korean oil shale at different heating rates of $10,15,20$ and $25^{\circ} \mathrm{C} / \mathrm{min}$ from ambient temperature to $600{ }^{\circ} \mathrm{C}$. Experiments were performed twice to ensure repeatability.

The experimental conditions are as follows:

- Carrier gas: nitrogen with the purity of $99.99 \%$;

- Flow rate of carrier gas: $60 \mathrm{~mL} \cdot \mathrm{min}^{-1}$;

- Final pyrolysis temperature: $600{ }^{\circ} \mathrm{C}$;

- Weight of the sample: $10-20 \mathrm{mg}$.

\subsection{Mathematical model}

It is assumed that oil shale pyrolysis is first-order reaction, so the kinetic equation of oil shale pyrolysis can be described with the following equation:

$$
\frac{\mathrm{d} x}{\mathrm{~d} t}=A \exp \left(-\frac{E}{R T}\right)(1-x)
$$

The 3-spline interpolation equation can be used for calculation of the pyrolysis rate of oil shale samples:

$$
\begin{aligned}
\frac{\mathrm{d} x}{\mathrm{~d} T}(T) & =\frac{6}{h_{j}^{2}}\left[\frac{1}{h_{j}}\left(T_{j+1}-T\right)^{2}-\left(T_{j+1}-T\right)\right] x_{\mathrm{j}}+\frac{6}{h_{j}^{2}}\left[\left(T-T_{j}\right)-\frac{1}{h_{j}}\left(T-T_{j}\right)^{2}\right] x_{j+1} \\
+ & \frac{1}{h_{j}}\left[\frac{3}{h_{j}}\left(T_{j+1}-T\right)^{2}-2\left(T_{j+1}-T\right)\right] \beta_{j}-\frac{1}{h_{j}}\left[2\left(T-T_{j}\right)-\frac{3}{h_{j}}\left(T-T_{j}\right)^{2}\right] \beta_{j+1}
\end{aligned}
$$

When solving equation, the boundary conditions are as follows:

$$
\left.\frac{\mathrm{d}^{2} x}{\mathrm{~d} T^{2}}\right|_{x \rightarrow 0}=\left.\frac{\mathrm{d}^{2} x}{\mathrm{~d} T^{2}}\right|_{x \rightarrow 1}=0
$$

Consider constant heating rate $\beta=\mathrm{d} T / \mathrm{d} t$, to obtain

$$
\frac{\mathrm{d} x}{\mathrm{~d} t}=\frac{\mathrm{d} x}{\mathrm{~d} T} \times \beta
$$

Substituting Eq. (4) into Eq. (1) give Eq. (5):

$$
\frac{\mathrm{d} x}{\mathrm{~d} T}=\frac{A}{\beta} \exp \left(-\frac{E}{\mathrm{R} T}\right)(1-x)
$$

\subsubsection{Differential method}

Taking the logarithm of Eq. (5) will give the following equation:

$$
\ln \left[\frac{\frac{\mathrm{d} x}{\mathrm{~d} t}}{1-x}\right]=\ln A-\frac{E}{\mathrm{R} T}
$$

Linear regression of $\ln [(\mathrm{d} x / \mathrm{d} t) /(1-x)]$ vs. $1 / T$ in Eq. (6), the apparent activation energy $E$ and apparent frequency factor $A$ can be determined from the slope and intercept of the regression line, respectively. 


\subsubsection{Integral method}

The integral form of Eq. (5) is

$$
\int_{0}^{x} \frac{\mathrm{d} x}{(1-x)}=\int_{T_{0}}^{T} \frac{A}{\beta} \exp \left(-\frac{E}{\mathrm{R} T}\right) \mathrm{d} T
$$

When $T \gg>T_{0}$, the approximate integral of Eq. (7) will give Eq. (8):

$$
\ln \left\{\frac{-[\ln (1-x)](E+2 \mathrm{R} T)}{T^{2}}\right\}=\ln \frac{A \mathrm{R}}{\beta}-\frac{E}{\mathrm{R} T}
$$

The relationship of $\ln \left[-(E+2 \mathrm{R} T) \ln (1-x) / T^{2}\right]$ vs. $1 / T$ is linear one. The slope of the plot is equal to $E / R$, from which the value of the activation energy can be easily estimated. The intercept of the plot allows to obtain the apparent frequency factor, $A$.

\section{Results and discussion}

\subsection{Pyrolysis of oil shale}

Table 1 shows the Fischer Assay analysis result of the oil shale sample. The oil yield of the oil shale sample is 12.14 wt $\%$, higher than that of Maoming oil shale $(8.80 \mathrm{wt} \%)$ and Fushun oil shale (6.78 wt \%) (China) (Li and Yue, 2003). If our samples are representative, the oil shale deposit in North Korea has great development potential. The water content of $7.74 \mathrm{wt} \%$ is so high that it may result in cracking problems during the pyrolysis process. Table 1 shows that the North Korean oil shale has high oil yield, high moisture content and medium retorting gas content.

Table 1 Fischer Assay analysis of North Korean oil shale (Air Received basis, ar \%)

\begin{tabular}{cccc}
\hline Shale oil, wt $\%$ & Water, wt $\%$ & Semi-coke, wt $\%$ & Retorting gas, wt $\%$ \\
\hline 12.14 & 7.74 & 75.87 & 4.25 \\
\hline
\end{tabular}

Fig. 1 shows that the oil yield and retorting gas increase with the rise of temperature. When the temperature reaches $500{ }^{\circ} \mathrm{C}$, the oil yield has stopped increasing. So the optimum retorting temperature can be determined as about $500{ }^{\circ} \mathrm{C}$.

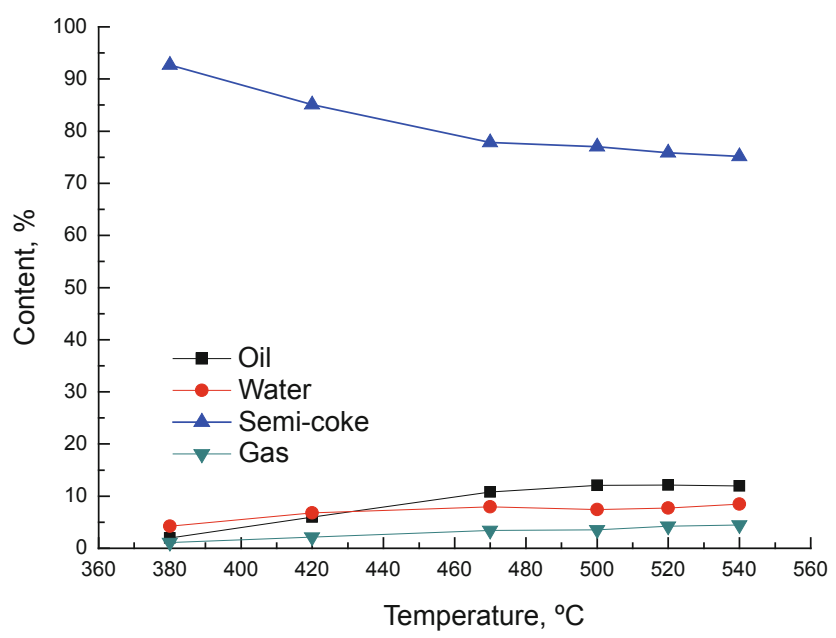

Fig. 1 Fischer assay (FA) analysis of oil yield at different retorting temperatures for the North Korean oil shale
Table 2 shows that the ash content of the North Korean oil shale samples is $53 \mathrm{wt} \%$, lower than that of most oil shale (with $70 \mathrm{wt} \%-80 \mathrm{wt} \%$ ash content) in China (Qian and Yin, 2010). Table 2 also shows that the fixed carbon and ash content of oil shale are lower than those of semi-coke, because of the complete combustion of combustible material and the decomposition of minerals of the oil shale.

The heat value of the North Korean oil shale in Table 3 is more than $13,000 \mathrm{~kJ} / \mathrm{kg}$, higher than the highest heat value $(11,700 \mathrm{~kJ} / \mathrm{kg}$ ) of oil shale in China (Qian and Yin, 2010). The heat value of semi-coke is lower than that of corresponding oil shale due to the high content of ash in semi-coke in Table 2. The North Korean oil shale with the heat value of its semi-coke more than $2,000 \mathrm{kcal} / \mathrm{kg}$ can be classified as a carbonaceous oil shale. The semi-coke of North Korean oil shale not only can be used as boiler fuel for power generation, but also can be used as heating source for retorting oil shale.

Table 2 Proximate analysis results of North Korean oil shale and its semicoke (Air received basis, ar \%)

\begin{tabular}{ccccc}
\hline Sample & Moisture, \% & Volatile, \% & Ash, \% & Fixed carbon, \% \\
\hline Oil shale & 4.27 & 25.81 & 52.98 & 16.94 \\
Semi-coke & 0 & 6.92 & 67.22 & 25.86 \\
\hline
\end{tabular}

Table 3 Heat value of North Korean oil shale and its semi-coke (Air received basis, ar \%)

\begin{tabular}{cc}
\hline Sample & $\mathrm{kJ} / \mathrm{kg}$ \\
\hline Oil shale & 13423 \\
Semi-coke & 10702 \\
\hline
\end{tabular}

Table 4 shows that the sulfur content of North Korean oil shale is high, and that low temperature retorting of oil shale is unfavorable on environmental grounds. But there are some positive factors for the oil shale, such as low carbon content and high hydrogen/carbon ratio, which is favorable for producing high quality shale oil. The oxygen content and oxygen/carbon ratio of the North Korean oil shale are also high, similar to that of oil shale from Fushun and Maoming, China (Qian and Yin, 2010). The hydrogen content and oxygen/carbon ratio of the semi-coke decrease as the organic matter of oil shale is converted into shale oil. Table 4 also shows that the oxygen content of the semi-coke is lower than that of the corresponding oil shale sample, indicating that the oxygen of oil shale is transferred into gaseous or liquid products during the pyrolysis process. The sulfur content of the oil shale sample is lower than that of semi-coke, implying that the mineral pyrite is the main sulfur source in the oil shale.

Table 5 shows that the mechanical strength and thermal stability $\left(\mathrm{BTS}_{+13}\right.$ and $\left.\mathrm{BTS}_{-3}\right)$ of the oil shale from North Korea are $87.3 \mathrm{wt} \%, 84.1 \mathrm{wt} \%$ and $5.84 \mathrm{wt} \%$, respectively. The results are similar to these of Fushun oil shale in China (Qian and Yin, 2010). So the Fushun-type retort furnace and SJrectangular retort furnace, which are used for retorting bulk oil shale, could be used to process the North Korean oil shale. 
Table 4 Ultimate analysis of North Korean oil shale, semi-coke and shale oil (Dry basis, $\mathrm{d} \%$ )

\begin{tabular}{cccccc}
\hline Sample & $\mathrm{C}, \mathrm{wt} \%$ & $\mathrm{H}, \mathrm{wt} \%$ & $\mathrm{O}, \mathrm{wt} \%$ & $\mathrm{~N}, \mathrm{wt} \%$ & $\mathrm{~S}, \mathrm{wt} \%$ \\
\hline Oil shale & 30.56 & 3.25 & 10.19 & 0.90 & 5.59 \\
Semi-coke & 25.98 & 1.30 & 8.12 & 1.07 & 5.81 \\
Shale oil & 80.97 & 10.98 & 3.62 & 0.77 & 0.91 \\
\hline
\end{tabular}

Table 5 Analysis of mechanical strength and thermal stability (Air received basis, ar \%)

\begin{tabular}{cccc}
\hline \multirow{2}{*}{ Sample } & Mechanical strength ${ }^{1}$, wt $^{*} \%$ & \multicolumn{2}{c}{ Thermal stability $^{2}$, wt $\%$} \\
\cline { 3 - 4 } & & BTS $_{+13}$ & BTS $_{-3}$ \\
\hline Oil shale & 87.3 & 84.1 & 5.84
\end{tabular}

Notes: 1 and 2 are calculated by the methods of mechanical strength and thermal stability of coal (Yang et al, 1983).

Table 6 indicates that the ash composition is mainly $\mathrm{SiO}_{2}$, up to $60 \mathrm{wt} \%$. The second largest content is $\mathrm{Al}_{2} \mathrm{O}_{3}$, about 22 $\mathrm{wt} \%$. The third is $\mathrm{Fe}_{2} \mathrm{O}_{3}$ with $12.6 \mathrm{wt} \%$. The rest of mineral content are relatively low. The raw material for producing ceramsite, (manufactured in China) has $\mathrm{SiO}_{2}, \mathrm{Al}_{2} \mathrm{O}_{3}$ and $\mathrm{Fe}_{2} \mathrm{O}_{3}$ contents of 48-68 wt \%, 12-18 wt \%, 5-10 wt \%, respectively (Chen et al, 2004). So the North Korean shale ash is a good raw material for producing high strength ceramsite. Besides, it can also be used to produce cement and other building materials when mixed with other ingredients.

Table 6 Composition analysis for ash from North Korean oil shale

\begin{tabular}{cc||cc}
\hline Component & Content, wt $\%$ & Component & Content, wt $\%$ \\
\cline { 3 - 4 } $\mathrm{SiO}_{2}$ & 60.06 & $\mathrm{~K}_{2} \mathrm{O}$ & 0.14 \\
$\mathrm{Al}_{2} \mathrm{O}_{3}$ & 22.01 & $\mathrm{Na}_{2} \mathrm{O}$ & 1.87 \\
$\mathrm{Fe}_{2} \mathrm{O}_{3}$ & 12.6 & $\mathrm{MnO}_{2}$ & 0.15 \\
$\mathrm{TiO}_{2}$ & 0.74 & $\mathrm{SO}_{3}$ & 0.75 \\
$\mathrm{CaO}$ & 0.63 & $\mathrm{P}_{2} \mathrm{O}_{5}$ & 0.12 \\
$\mathrm{MgO}$ & 0.83 & & \\
\hline
\end{tabular}

\subsection{Properties of North Korean shale oil}

Table 7 shows that the North Korean shale oil has the following properties: low density, low viscosity, low flash point and low freezing point compared with these of Fushun shale oil (Song, 2004). The freezing point of North Korean shale oil is $29{ }^{\circ} \mathrm{C}$, resulting in poor fluidity. But the shale oil can be processed to produce gasoline and diesel due to its high saturated hydrocarbon and aromatic contents. So the North Korean shale oil can be considered as an important source of transportation fuels.

Table 8 shows that the initial boiling point (IBP) of North Korean shale oil is $70{ }^{\circ} \mathrm{C}$ and the final boiling point (FBP) is $558{ }^{\circ} \mathrm{C}$. The fraction (about $11.5 \mathrm{wt} \%$ ) obtained at the temperature lower than $180{ }^{\circ} \mathrm{C}$ is the gasoline fraction. The diesel fraction obtained at temperatures ranging from $180{ }^{\circ} \mathrm{C}$ to $360{ }^{\circ} \mathrm{C}$ is $41.5 \mathrm{wt} \%$. The fraction above $360{ }^{\circ} \mathrm{C}$ is heavy oil (47 wt \%). Therefore, the North Korean shale oil can be classified as high quality light shale oil.

Table 7 Properties of North Korean shale oil

\begin{tabular}{ccc}
\hline Analysis items & North Korean shale oil & Fushun shale oil \\
\hline Viscosity $\left(50{ }^{\circ} \mathrm{C}\right), \mathrm{mm}^{2} \cdot \mathrm{s}^{-1}$ & 5.45 & 11.22 \\
Freezing point, ${ }^{\circ} \mathrm{C}$ & 29 & 36 \\
Density, $\mathrm{g} \cdot \mathrm{cm}^{-3}$ & 0.887 & 0.9033 \\
Flash point, ${ }^{\circ} \mathrm{C}$ & 37 & 133 \\
Carbon residue, $\mathrm{wt} \%$ & 1.05 & - \\
Ash, wt $\%$ & 0.008 & 0.08 \\
Mechanical impurity, wt $\%$ & Trace & 0.44 \\
Water, wt $\%$ & Trace & 0.24 \\
Saturate, $\mathrm{wt} \%$ & 38.54 & - \\
Aromatics, $\mathrm{wt} \%$ & 26.02 & - \\
Resin, wt $\%$ & 28.88 & 42 \\
Asphaltene, $\mathrm{wt} \%$ & 6.55 & 0.85 \\
\hline
\end{tabular}

Table 8 Simulation distillation of North Korean shale oil

\begin{tabular}{cc||cc}
\hline $\begin{array}{c}\text { Cut fraction } \\
\text { wt } \%\end{array}$ & $\begin{array}{c}\text { Temperature } \\
{ }^{\circ} \mathrm{C}\end{array}$ & $\begin{array}{c}\text { Cut fraction, } \\
\mathrm{wt} \%\end{array}$ & $\begin{array}{c}\text { Temperature } \\
{ }^{\circ} \mathrm{C}\end{array}$ \\
\hline IBP & 70 & 53 & 360 \\
2 & 104 & 66 & 401 \\
11 & 178 & 93 & 499 \\
12 & 186 & FBP & 558 \\
15 & 203 & & \\
\hline
\end{tabular}

\subsection{Retorting gas composition}

Table 9 shows the composition of retorting gas from pyrolysis of the North Korean oil shale. It can be seen that $\mathrm{CH}_{4}$ (the most abundant), $\mathrm{H}_{2}, \mathrm{CO}_{2}, \mathrm{H}_{2} \mathrm{~S}, \mathrm{CO}$, and $\mathrm{C}_{2}-\mathrm{C}_{5}$ hydrocarbons are the major components of retorting gas. The heat value of retorting gas is more than $900 \mathrm{~kJ} / \mathrm{mol}$ (The averaged heat value of retorting gas is $939.59 \mathrm{KJ} / \mathrm{mol}$ ). The averaged molecular weight of retorting gas is $26.25 \mathrm{~g} / \mathrm{mol}$ and the averaged specific heat is $11.34 \mathrm{~J} /\left(\mathrm{kg} \cdot{ }^{\circ} \mathrm{C}\right)$. The $\mathrm{H}_{2} \mathrm{~S}$ content is $8.68 \mathrm{wt} \%$, which is environmentally undesirable. If the retorting gas is used for oil shale pyrolysis as heat source, the exhaust gas must be desulfurized before emission.

Table 9 Composition of retorting gas from pyrolysis of North Korean oil shale

\begin{tabular}{cc||cc}
\hline Component & Content, wt $\%$ & Component & Content, wt \% \\
\cline { 3 - 4 } Methane & 18.27 & Pentane & 1.43 \\
Ethane & 11.45 & Hydrogen & 29.92 \\
Ethylene & 4.81 & Carbon dioxide & 9.88 \\
Propane & 4.89 & Carbon monoxide & 2.84 \\
Propene & 4.94 & Hydrogen sulfide & 8.68 \\
Butane & 2.08 & & \\
\hline
\end{tabular}




\subsection{Kinetics model}

The TG curve in Fig. 2 shows that the pyrolysis of North Korean oil shale goes through two stages of mass loss. The first occurs below $200{ }^{\circ} \mathrm{C}$ with a weight loss decline from $100 \mathrm{wt} \%$ to $97 \mathrm{wt} \%$ due to the evaporation of moisture. The change is almost consistent with the moisture content (Table 2 ). The second stage of mass loss occurs due to the release of volatile hydrocarbons from $200{ }^{\circ} \mathrm{C}$ to $600{ }^{\circ} \mathrm{C}$, where the sharp decline of the weight loss curve is attributed to the decomposition of bitumen and kerogen present in oil shale.

Kinetic parameters calculated by the differential (Eq. 6) and integral methods (Eq. 8) are shown in Table 10 and Table 11 , respectively. It can be seen that the values of activation energies $E$ and frequency factor $A$ obtained by the differential method (Eq. 6) are markedly different from those obtained by the integral method (Eq. 8). The difference is attributed to the substitution for $\mathrm{d} x_{i} / \mathrm{d} t_{i}$ using $\Delta x_{i} / \Delta t_{i}$ in the differential method and the approximate integration in the integral method. The results are basically identical with literature reports (Olivella and De las Heras, 2008). The relative coefficient obtained from the differential method (Eq. 6) and the integral method (Eq. 8) (Table 10 and 11) are more than 0.96 for each heating rate. Therefore, the overall first-order reaction model (including both the integral and differential methods) is valid for the temperature region below $600{ }^{\circ} \mathrm{C}$ to describe pyrolysis

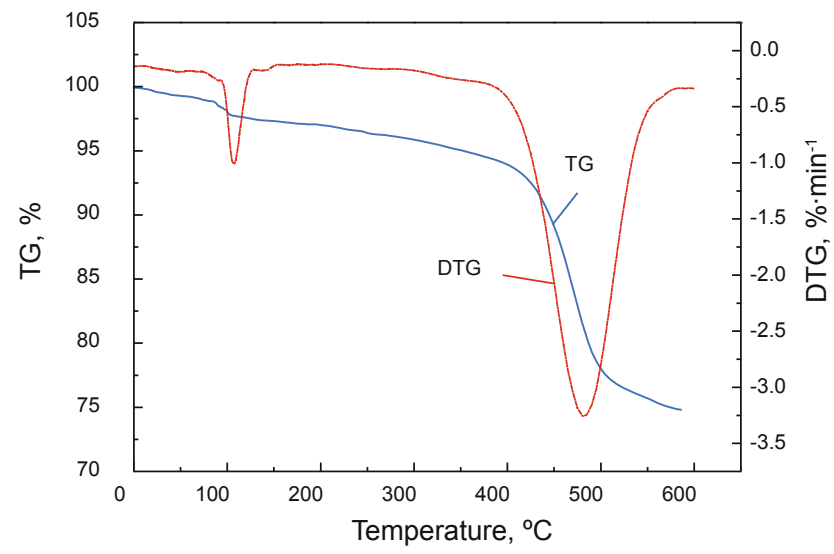

Fig. 2 Thermal gravity/differential thermal gravity (TG/DTG) curves of North Korean oil shale at a heating rate of $15^{\circ} \mathrm{C} / \mathrm{min}$

of the North Korean oil shale.

In addition, the effect of the heating rate on the activation energy values can be seen in Table 10 and Table 11. The activation energy values decrease with an increase of heating rate, in accordance with the data in literature (Torrente and Galan, 2001; Olivella and De las Heras, 2008). This is attributed to a shorter time for a particular conversion at faster heating rates and causing transport limitations due to heat transfer.

Table 10 Kinetic parameters of the North Korean oil shale calculated by the differential method

\begin{tabular}{ccccc}
\hline $\begin{array}{c}\text { Heating rate } \\
{ }^{\circ} \mathrm{C} / \mathrm{min}\end{array}$ & Conversion range & $\begin{array}{c}\text { Activation energy }(E) \\
\mathrm{kJ} / \mathrm{mol}\end{array}$ & $\begin{array}{c}\text { Frequency factor }(A) \\
\mathrm{min}^{-1}\end{array}$ & $\begin{array}{c}\text { Relative } \\
\text { coefficient }\end{array}$ \\
\hline 10 & $0.06-0.95$ & 113.51 & $2.37 \mathrm{E}+06$ & 0.9831 \\
15 & $0.06-0.95$ & 107.62 & $1.56 \mathrm{E}+06$ & 0.9694 \\
20 & $0.06-0.95$ & 105.05 & $1.52 \mathrm{E}+06$ & 0.9601 \\
25 & $0.06-0.95$ & 104.03 & $1.45 \mathrm{E}+06$ & 0.9663 \\
\hline
\end{tabular}

Table 11 Kinetic parameters of the North Korean oil shale calculated by the integral method

\begin{tabular}{ccccc}
\hline $\begin{array}{c}\text { Heating rate } \\
{ }^{\circ} \mathrm{C} / \mathrm{min}\end{array}$ & Conversion range & $\begin{array}{c}\text { Activation energy }(E) \\
\mathrm{kJ} / \mathrm{mol}\end{array}$ & $\begin{array}{c}\text { Frequency factor }(A) \\
\text { min }^{-1}\end{array}$ & $\begin{array}{c}\text { Relative } \\
\text { coefficient }\end{array}$ \\
\hline 10 & $0.06-0.95$ & 98.41 & $1.85 \mathrm{E}+08$ & 0.9818 \\
15 & $0.06-0.95$ & 86.99 & $3.16 \mathrm{E}+07$ & 0.9821 \\
20 & $0.06-0.95$ & 79.61 & $8.93 \mathrm{E}+06$ & 0.9722 \\
25 & $0.06-0.95$ & 76.72 & $1.34 \mathrm{E}+07$ & 0.9726 \\
\hline
\end{tabular}

From Tables 10 and 11, $\ln A-E$ relationship equations can be described as $\ln A=a E+b$. Fig. 3 shows the curves of $\ln A$ vs. $E$ at different heating rates by using the integral and differential methods. The equations of the linear regression analysis shown in Fig. 3 are

Differential method:

$$
\ln A=0.0517 E+8.7779 \quad(R=0.9686)
$$

Integral method:

$$
\ln A=0.1344 E+5.6932 \quad(R=0.9677)
$$

\section{Conclusion}

The North Korean oil shale with an oil yield of $12.1 \mathrm{wt} \%$ indicates a potentially valuable resource. It is also characterized for high moisture content. The heat value of its semi-coke is more than $10,000 \mathrm{~kJ} / \mathrm{kg}$, so it can be classified as a carbonaceous oil shale. The mechanical strength of the North Korean oil shale is similar to that of Fushun oil shale 


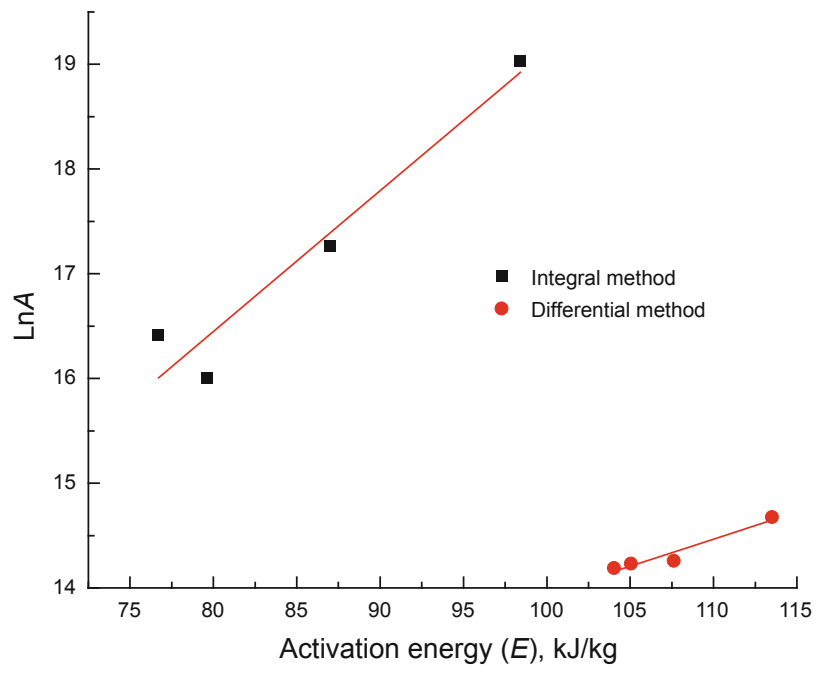

Fig. 3 Ln $A$ vs $E$ curves of North Korean oil shale using integral and differential methods

in China, so that it can be processed by the Fushun-type retort. The shale oil has low density, viscosity, flash point and mechanical impurity. It can be used for producing gasoline and diesel due to the high saturate, aromatic and resin content. The retorting gas is mainly composed of $\mathrm{CH}_{4}$ (the most abundant), $\mathrm{H}_{2}, \mathrm{CO}_{2}, \mathrm{H}_{2} \mathrm{~S}, \mathrm{CO}$, and $\mathrm{C}_{2}-\mathrm{C}_{5}$ hydrocarbons. The heat value of it is more than $900 \mathrm{~kJ} / \mathrm{mol}$, higher than that from Chinese oil shales. In addition, the retorting gas with high sulfur content must be desulfurized before it can be used to supply heat for self-retorting. Besides the shale ash with up to $60 \% \mathrm{SiO}_{2}$ is a good raw material for producing high strength artificial ceramsite. It can also be used for producing cement and other building materials when mixed with other ingredients. The overall first-order reaction model, using both the integral and differential methods, is suitable to calculate the activation energies and frequency factors. It shows that the activation energy decreases with an increase of the heating rate. $\operatorname{Ln} A$ and $E$ fit a good straight line.

\section{Nomenclatures}

$\begin{array}{ll}A & \text { Frequency factor, } \mathrm{min}^{-1} ; \\ E & \text { Activation energy, } \mathrm{kJ} / \mathrm{mol} ; \\ R & \text { General gas constant, } 8.314 \mathrm{~kJ} /(\mathrm{mol} \cdot \mathrm{K}) ; \\ t & \text { Pyrolysis time, } \mathrm{s} ; \\ T & \text { Pyrolysis temperature, }{ }^{\circ} \mathrm{C} ; \\ x & \text { Fractional conversion of oil shale; } \\ \beta=\mathrm{d} x / \mathrm{d} T & \text { Constant heating rate, }{ }^{\circ} \mathrm{C} / \mathrm{min} ; \\ h=T_{j+1}-T_{j} & \text { Temperature interval; } \\ j & \text { Number of integral }\end{array}$

\section{Acknowledgements}

This authors are grateful for the National Basic Research Program of China (973 programs, No. 2014CB744302) and Taishan Scholar Constructive Engineering Foundation of Shandong province, China (No. ts20120518).

\section{References}

Al-Ayed O S, Matouq M, Anbar Z, et al. Oil shale pyrolysis kinetics and variable activation energy principle. Applied Energy. 2010. 87(4): 1269-1272

Al-Harahsheh M, Al-Ayed O, Robinson J, et al. Effect of demineralization and heating rate on the pyrolysis kinetics of Jordanian oil shales. Fuel Processing Technology. 2011. 92(9): 18051811

Al-Harahsheh M, Kingman S, Saeid A, et al. Dielectric properties of Jordanian oil shales. Fuel Processing Technology. 2009. 90(10): 1259-1264

Altun N E, Hicyilmaz C, Hwang J Y, et al. Beneficiation of Himmetoglu oil shale by flotation as a solid fuel substrate. Part 1. Materials characteristics and flotation behavior. Energy Fuels. 2006a. 20 (1): 214-221

Altun N E, Hiçyilmaz C, Hwang J Y, et al. Oil shales in the world and Turkey; reserves, current situation and future prospects: a review. Oil Shale. 2006b. 23(3): 211-227

Bai J R, Wang Q, Hu A J, et al. The pyrolysis characteristics of Maoming oil shales. Journal of Northeast Dianli University. 2006. 24(2): 73-78 (in Chinese)

Bhargava S, Awaja F and Subasinghe N D. Characterization of some Australian oil shale using thermal, X-ray and IR techniques. Fuel. 2005. 84(6): 707-715

Chi Y L, Li S Y, Ma Y H, et al. Study of pyrolysis characteristics and kinetics of Long-kou oil shale. Journal of China University of Petroleum. 2007. 31(4): 112-115 (in Chinese)

Chen Y L, Mao C S, Li Y, et al. The development and production of super-light ceramsite. Building Block and Block Building. 2004.18(03): 30-33 (in Chinese)

Dyni J R. Geology and resources of some world oil shale deposits. Oil Shale. 2003. 20(3): 193-252

Ehinola O A, Sonibare O O and Akanbi O A. Economic evaluation, recovery techniques and environmental implications of the oil shale deposit in the Abakaliki Anticlinorium, southeastern Nigeria. Oil Shale. 2005. 22 (1): 5-19

El Harfi K, Mokhlisse A, Chanaa M B, et al, Pyrolysis of the Moroccan (Tarfaya) oil shales under microwave irradiation. Fuel. 2000. 79(7): 733-742

Fang Z H, Li S Y, Ma G L, et al. Reaction mechanism and kinetics of pressurized pyrolysis of Chinese oil shale in the presence of water. Petroleum Science. 2012. 9(4): 532-534

Hakala J A, Stanchina W, Soong Y, et al. Influence of frequency, grade, moisture and temperature on Green River oil shale dielectric properties and electromagnetic heating processes. Fuel Processing Technology. 2011. 92(1): 1-12

Hascakir B and Akin S. Recovery of Turkish oil shales by electromagnetic heating and determination of the dielectric properties of oil shales by an analytical method. Energy Fuels. 2010. 24(1): 503-509

Johannes I, Kruusement K and Veski R. Evaluation of oil potential and pyrolysis kinetics of renewable fuel and shale samples by Rock-Eval analyzer. Journal of Analytical Applied Pyrolysis. 2007. 79(1-2): 183-190

Li S Y and Yue C T. Study of pyrolysis kinetics of oil shale. Fuel. 2003. 82(3): 337-342

Martins M F, Salvador S, Thovert J-F, et al. Co-current combustion of oil shale-Part 1: Characterization of the solid and gaseous products. Fuel. 2010. 89(1): 144-151

Miao Z Y, Wu G G, Meng X L, et al. Study of pyrolysis characteristics and kinetic of Daqing oil shale. Coal Conversion. 2011. 34(1): 70-73 (in Chinese)

Na J G, Im C H, Chung S H, et al. Effect of oil shale retorting temperature on shale oil yield and properties. Fuel. 2012. 95(1): 131-135

Olivella M A and De las Heras F X C. Evaluation of linear kinetic 
methods from pyrolysis data of Spanish oil shales and coals. Oil Shale. 2008. 25(2): 227-245

Qian J L, Wang J Q and Li S Y. Oil shale development in China. Oil Shale. 2003. 20(3S): 356-359

Qian J L and Yin L. Oil Shale-Petroleum Alternative. Beijing: China Petrochemical Press. 2010. 49-60

Sert M, Ballİce L, Yüksel M, et al. The effects of acid treatment on the pyrolysis of Göynük oil shale (Turkey) by thermo gravimetric analysis. Oil Shale. 2012. 29(1): 51-62

Song Y. Properties and processing scheme of Fushun shale oil. Coal Processing \& Comprehensive Utilization. 2004. 14(4): 49-51(in Chinese)

Sun Y H, Bai F T, Liu B Ch, et al. Characterization of the oil shale products derived via topochemical reaction method. Fuel. 2014. 115: 338-346

Tiwari $\mathrm{P}$ and Deo M. Compositional and kinetic analysis of oil shale pyrolysis using TGA-MS. Fuel. 2012. 94(1): 333-341

Tong J H, Han X X, Wang S, et al. Evaluation of structural characteristics of Huadian oil shale kerogen using direct techniques (Solid-State ${ }^{13} \mathrm{C}$ NMR, XPS, FT-IR, and XRD). Applied Energy. 2011. 25(9): 40064013

Torrente M C and Galan M A. Kinetics of the thermal decomposition of oil shale from Puertollano (Spain). Fuel. 2001. 80 (3): 327-334

Wang Q, Jiao G J, Liu H P, et al. Variation of the pore structure during microwave pyrolysis of oil shale. Oil Shale. 2010. 27(2): 135-146

Wang Q, Kong LW, Bai J R, et al. The pyrolysis characteristics and pores structure of oil shale of different densities. Energy Procedia. 2012. 17(A): 876-883

Wang W D and Zhou C Y. Retorting of pulverized oil shale in fluidizedbed pilot plant. Oil Shale. 2009. 26 (2): 108-113

Williams P T and Ahmad N. Investigation of oil-shale pyrolysis processing conditions using thermo-gravimetric analysis. Applied Energy. 2000. 66(2): 113-133

Yang J H, Chen W M and Duan Y L. Test Methods of Manual Coal. Beijng: Coal Industry Press. 1983. 533-537 (in Chinese)

(Edited by Zhu Xiuqin) 